\title{
Novitates Bruneienses, 4. New records in the Araliaceae, Araucariaceae, Arecaceae, Fagaceae, Musaceae and Thymelaeaceae
}

\author{
K.M. Wong ${ }^{1}$, Y.W. Low ${ }^{1}$, A.K. Muhammad Ariffin ${ }^{2}$ \& A.A. Joffre ${ }^{2}$ \\ ${ }^{1}$ Herbarium, Singapore Botanic Gardens, National Parks Board, \\ 1 Cluny Road, Singapore 259569 \\ wkm2000@gmail.com \\ ${ }^{2}$ Brunei National Herbarium, Forestry Department, \\ Ministry of Industry and Primary Resources, Jalan Menteri Besar, \\ Berakas, BB3910 Brunei Darussalam
}

\begin{abstract}
Aralia merrillii C.B.Shang (Araliaceae), Agathis lenticula de Laub. (Araucariaceae), Licuala collina Saw and L. miriensis Saw (Arecaceae), Lithocarpus bullatus Hatus. ex Soepadmo and L. hallieri (Seemen) A.Camus (Fagaceae), Musa lawitiensis var. suratii (Argent) Häkkinen (Musaceae) and Aquilaria microcarpa Baill. (Thymelaeaceae) are newly recorded for the Brunei flora.
\end{abstract}

Keywords. Angiosperms, Borneo, Brunei Darussalam, conservation, gymnosperms

\section{Introduction}

The Botanical Survey of Brunei Darussalam is a collaborative programme between the Government of Brunei Darussalam and the National Parks Board, Singapore, in which the Ministry of Industry and Primary Resources and the Forestry Department in Brunei partner the Singapore Botanic Gardens to continue botanical exploration and documentation in Brunei. In this fourth instalment of the series dedicated to reporting the scientific results of this collaboration, we record eight plant species new for the Brunei flora, in six different families. The baseline data, to assess whether a taxon is a new record or not, comes from Coode et al. (1996) and later taxonomic works in the particular groups. Conservation assessments for the species presented in this paper are based on IUCN (2012), adopted with a regional focus on Brunei. Herbaria acronyms of herbarium specimens examined follow Thiers (continuously updated).

\section{New records for Brunei}

\section{ARALIACEAE}

Aralia merrillii C.B.Shang, J. Nanjing Inst. Forest. 1985(2): 28 (1985). - Aralia scandens (Merr.) Ha, Novosti Sist. Vyssh. Rast. 11: 229 (1974), nom. illeg. non A. scandens Poir, Encycl. Suppl. 1: 419 (1811). - Acanthophora scandens Merr., Philipp. 
J. Sci., C. 13: 316 (1918). - TYPE: Philippines, Mindanao, Lake Lanao, Camp Keithley, 1 October 1906, M.S. Clemens 752 (holotype PNH, destroyed; isotype A [A00067728]). (Fig. 1)

Specimen examined. BRUNEI: Temburong: Ulu Temburong National Park, steep slope at LP 58, $1000 \mathrm{~m}$ asl, 6 Aug 2014, Wong \& Jangarun WKM 3363 (BRUN, SING).

This thorny scrambling-climbing species is known from the Malay Peninsula to the Philippines and Sulawesi, and in Borneo has been recorded on Mt Kinabalu (Philipson, 1979; Beaman et al., 2001). The tripinnate leaves, up to $1.5 \mathrm{~m}$ long, and large panicle, with the flowers or fruits in ultimate umbels, are distinctive. Besides that, Aralia merrillii is also the only Aralia species in Malesia to have a scrambling-climbing liana habit (Philipson, 1979). This species belongs to the section Aralia L. sect. Dimorphanthus (Miq.) Miq., for which the presence of prickles is a synapomorphy (Wen, 2004).

Provisional IUCN conservation assessment. Data Deficient (DD) (IUCN, 2012) for Brunei as this is the only collection known thus far. Its typical occurrence is disturbed or fringe habitats in montane localities, with the documented occurrence in the inner mountainous region of the Ulu Temburong National Park. Field observations are badly needed for a better understanding of its conservation status in Brunei.

\section{ARAUCARIACEAE}

Agathis lenticula de Laub., Blumea 25(2): 537 (1979). - TYPE: Sabah, Mt. Kinabalu, Park Headquarters, 9 August 1978, de Laubenfels P619 (holotype L; isotypes A [A00022582], K, RSA [RSA0000051], SAN, US [US00345172]). (Fig. 2)

Specimen examined. BRUNEI: Temburong: Ulu Temburong National Park, ridge W of LP 58, $1000 \mathrm{~m}$ asl, 6 Aug 2014, Wong \& Jangarun WKM 3303 (BRUN, SING).

This stately conifer was previously known only for the Crocker Range, including Mount Kinabalu, in Sabah, and is by no means rare on the ridges in this part of the Ulu Temburong National Park. It is not expected to occur in the Tutong and Belait districts because of the generally lower terrain there. The glaucous foliage, including somewhat asymmetric leaf with acute apex and base, as well as short-pedunculate male cones, are distinctive (Yii, 1995).

Provisional IUCN conservation assessment. Data Deficient (DD) (IUCN, 2012) for Brunei as this is the first and only collection recorded so far. As the montane ridges of the Ulu Temburong National Park are little explored, more specialised collections and detailed field observations of the taxon are badly needed for a better understanding of its conservation status in Brunei. Besides that, the species occurs within the Ulu Temburong National Park, and there are no imminent threats known to be present. 


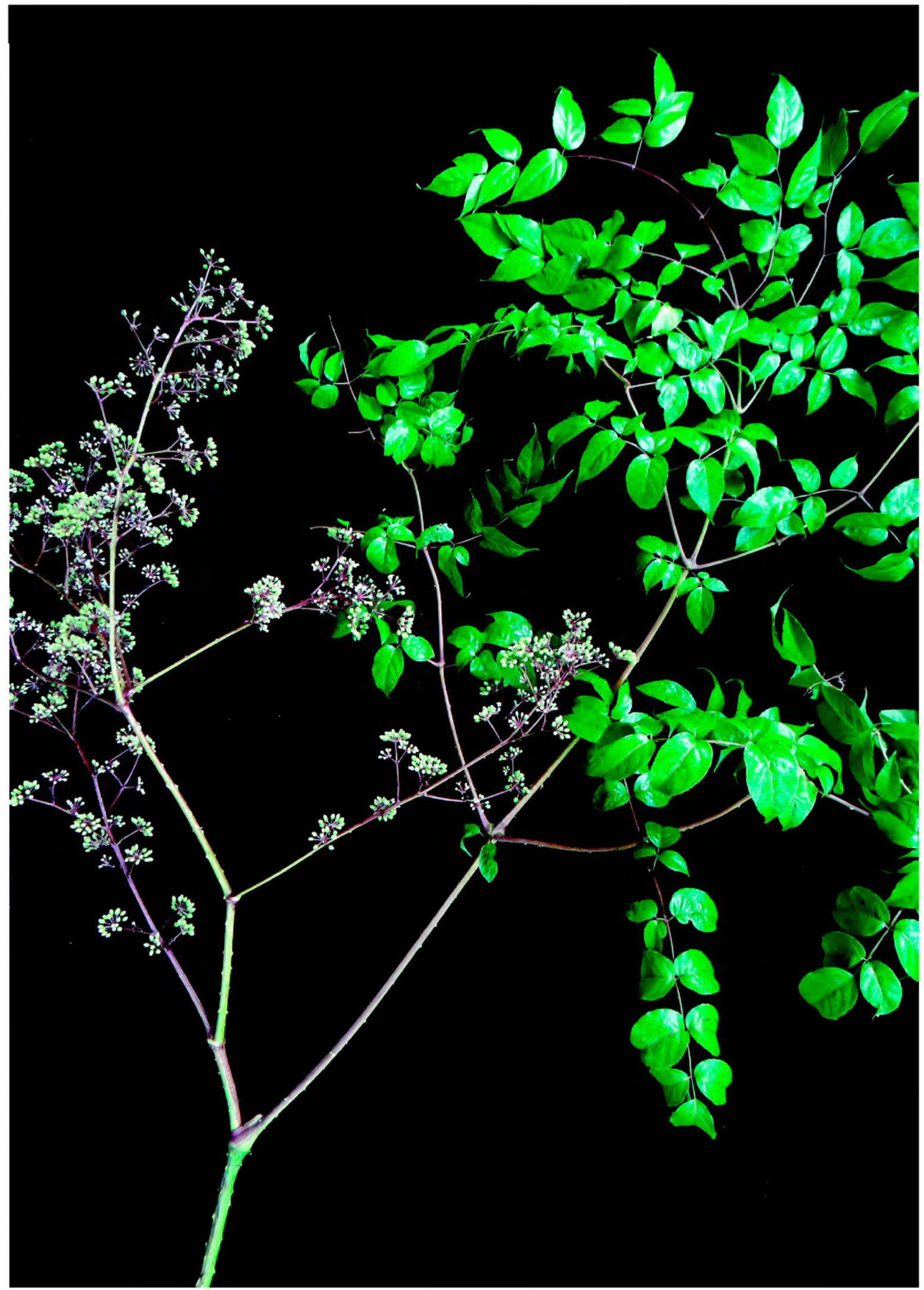

Fig. 1. Aralia merrillii C.B.Shang (Araliaceae), Wong \& Jangarun WKM 3363. (Photo: K.M. Wong) 


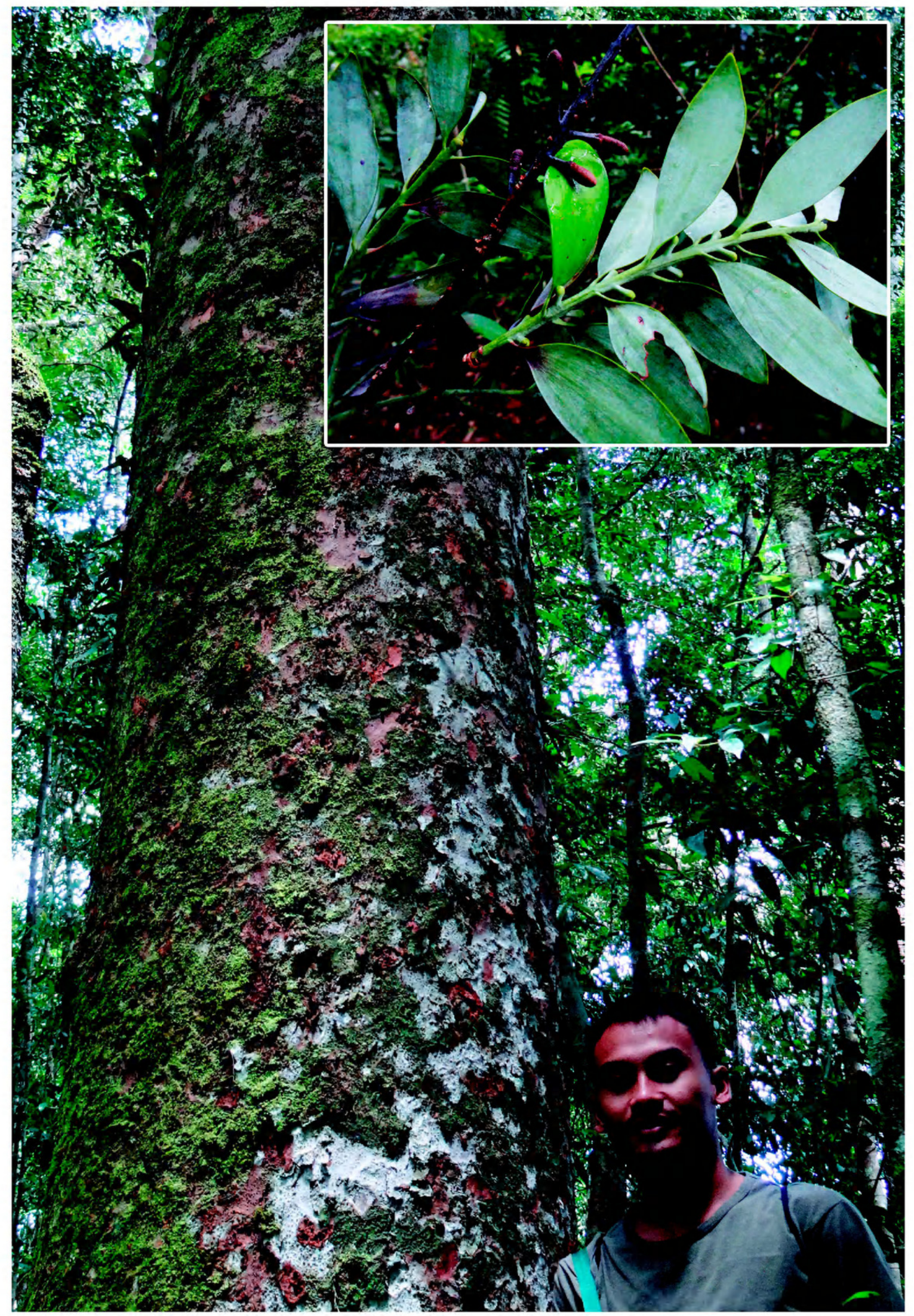

Fig. 2. Agathis lenticula de Laub. (Araucariaceae), the characteristic columnar bole with scaly-dippled bark and (inset) glaucous leaves and male cones. Wong \& Jangarun WKM 3303. (Photos: K.M. Wong) 


\section{ARECACEAE}

Licuala collina Saw, Kew Bull. 67(4): 599 (2012). - TYPE: Malaysia, Sarawak, Tama Abu Range, Bario, 1250 m, 6 November 1989, Dayang Awa \& Lee S 51191 (holotype $\mathrm{K}$; isotype SAR). (Fig. 3A)

Specimens examined. BRUNEI: Belait: Sukang, Labi Hills Forest Reserve, east of LP Ukur 16, $100 \mathrm{~m}$ asl, 24 Aug 1997, Niga BRUN 18698 (BRUN); Ulu Buau, Kampong Buau, 8 Mar 1999, Ariffin BRUN 19100 (BRUN). Temburong: Ulu Temburong National Park, ridge E of LP 58, c. $1000 \mathrm{~m}$ asl, 8 Aug 2014, Wong \& Jangarun WKM 3329 (BRUN, SING).

This was recorded as a lower montane forest palm and also with one occurrence in kerangas forest at $100 \mathrm{~m}$ asl (Saw, 2012). It is now also recorded at the lower elevation in Brunei in riparian Mixed Dipterocarp Forest. It would appear to have a general occurrence in the highland areas on the Setap Shale formation of Brunei and NE Sarawak and adjacent lower elevations.

This is a usually solitary palmlet $0.5-1.5 \mathrm{~m}$ high. The inflorescence is typically short, with a single partial inflorescence (unbranched or with few branches), without peduncular or rachis bracts. There are 3-5 leaf segments (in Sarawak 4-10 recorded), with the central segment broader and distinctly bifid, and frequently one of the halves further bearing a narrow division.

Provisional IUCN conservation assessment. Data Deficient (DD) (IUCN, 2012) for Brunei as the species is only recorded three times. However, all known Brunei populations exist within protected areas, namely, the Ulu Temburong National Park and Forest Reserves where disturbances are now curtailed. Meanwhile in Sarawak, Licuala collina has been categorised as Vulnerable (VU) by Saw (2012).

Licuala miriensis Saw, Kew Bull. 67(4): 628 (2012). - TYPE: Malaysia, Sarawak, Miri, Riam Road, 15 m, 3 December 1962, Au S 16794 (holotype SAR; isotypes K, L). (Fig. 3B-D)

Specimen examined. BRUNEI: Belait: Lumut, Sungai Liang, Bukit Agis-Agis, 24 Dec 2003, Ariffin BRUN 20467 (BRUN); Andulau Forest Reserve, Compartment 18, 13 Aug 2014, Wong, Ariffin \& Jangarun WKM 3392 (BRUN, SING).

This species was previously recorded only for the Miri-Lambir and Bintulu areas in Sarawak (Saw, 2012). The two collections here record it for Brunei for the first time.

It is a distinctive, elegant, slender-stemmed understorey palm to $1.5-2 \mathrm{~m}$ high with c. 20 narrow segments per leaf. Although Saw (2012) records 46 species of Licuala for Borneo, a number remain known only from scanty material, including the present species, which was diagnosed as having an inflorescence specimen "with proximal portion broken off" and peduncle, prophyll and peduncular bracts unknown. In the key provided in Saw (2012), Licuala miriensis is diagnosed through the lead 

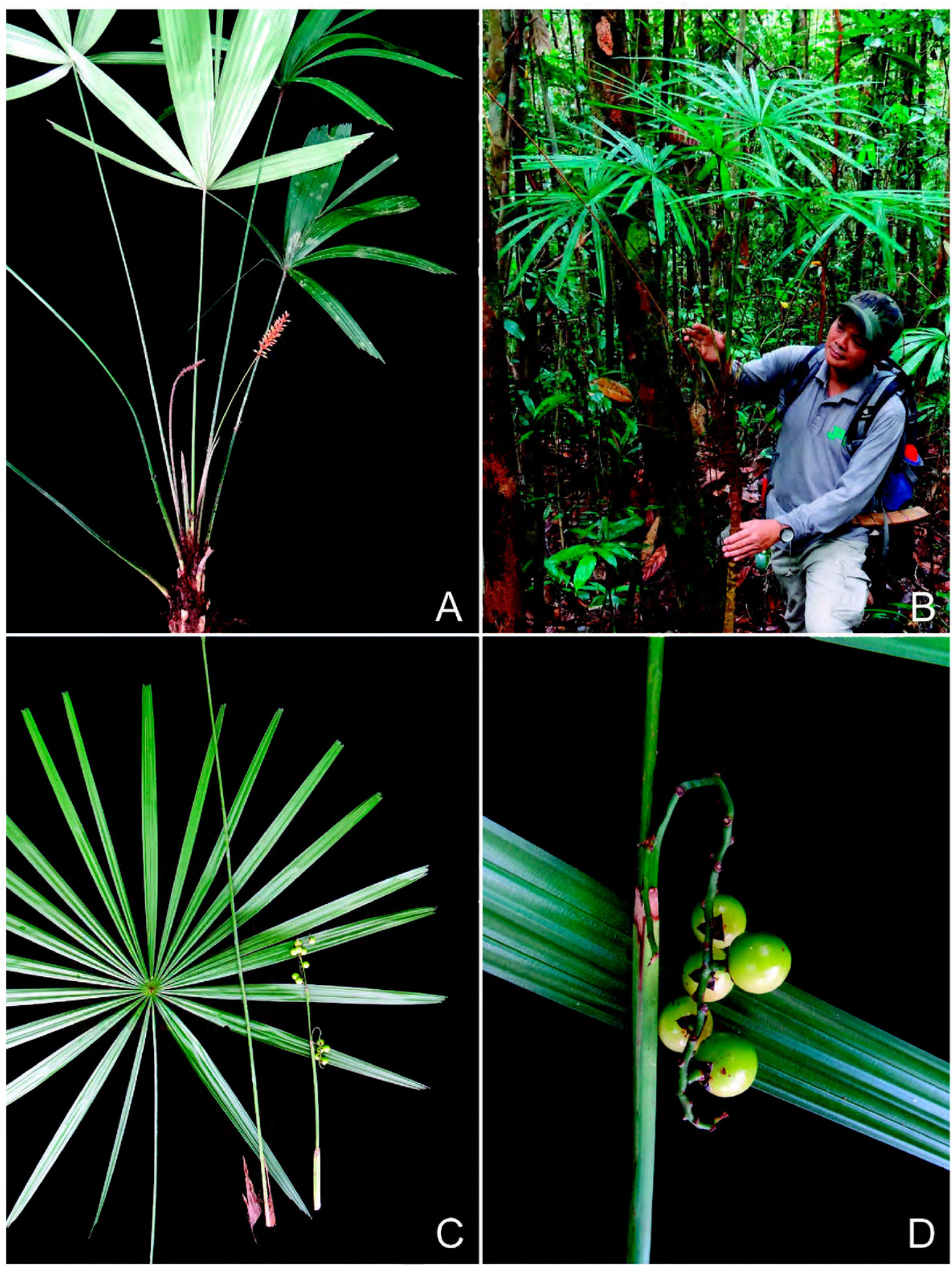

Fig. 3. New Licuala records. A. Licuala collina Saw. Wong \& Jangarun WKM 3329. B-D. Licuala miriensis Saw. Wong, Ariffin \& Jangarun WKM 3392. B. Habit. C. (from left) Leaf blade, lower portion of petiole, infructescence. D. Detail of partial infructescence. (Photos: K.M. Wong) 
in couplet 2 giving "All partial inflorescences spicate..." and, indeed, adopting this character helps derive the identity of the Brunei material as this species. However, as the Brunei material demonstrates, the other lead in couplet 2 ("Proximal partial inflorescence branched...") should have been the correct grouping because that partial inflorescence does have a solitary branch to $4 \mathrm{~cm}$ long (WKM 3392). This character is sometimes easily missed, including in BRUN 20467 where that branch has broken off and the remaining partial inflorescence looks spicate. [Following what should have been the correct lead for this species in this key, however, one arrives at the cluster of L. atrovirens Saw, L. mukahensis Saw, L. cordata var. ashtonii Saw and L. maculata Saw, species that differ in many characteristics from L. miriensis. Incidentally, the couplets 19 and 20 should have their numbers interchanged so as to match the correct character-states.]

Slight discrepancies remain between the Brunei material and the description in Saw (2012). The Brunei material has thin-membraneous to papery calyx lobes and corolla lobes, both in fresh (fruiting) and dried material, whereas the available description states that the calyx is "membranous... becoming thick" and the corolla is "fleshy becoming very thick in fruiting specimen". These are, however, minor differences that probably point simply to some variation present.

This extremely elegant Licuala deserves introduction into horticulture although, where we were able to observe this in Brunei, it is a solitary palm occurring with very low frequency in very moist shaded understorey conditions, and probably also slowgrowing. It is not known how this species might adapt and respond to an increased light regime.

Provisional IUCN conservation assessment. Data Deficient (DD) (IUCN, 2012) for Brunei as the species is only known from two localities so far. However, this status needs reassessment for a better understanding of its conservation status in Brunei, as more botanical explorations are made. Meanwhile, its probable status in Sarawak is considered to be Endangered (EN A2c) (Saw, 2012).

\section{FAGACEAE}

Lithocarpus bullatus Hatus. ex Soepadmo, Reinwardtia 8: 223 (1970). - TYPE: Borneo, Sabah, Mt. Kinabalu, 15 April 1933, J. \& M.S. Clemens 32715 (holotype $\mathrm{BO}$; isotypes A [A00033959], BM [BM000951969], K [K000832515], L, NY [NY00248587], UC). (Fig. 4A)

Specimen examined. BRUNEI: Temburong: Ulu Temburong National Park, ridge E of LP 58, c. $1000 \mathrm{~m}$ asl, 8 Aug 2014, Wong WKM 3323 (BRUN, SING).

The type of this species is $J$. \& M.S. Clemens 32715 from Mount Nungkok, a minor peak of the Kinabalu massif, at 1200-1500 m elevation in lower montane forest (Soepadmo, 1970). It is a Bornean endemic not uncommon in lower to upper montane forest to $3000 \mathrm{~m}$ on Mount Kinabalu and the Crocker Range in Sabah, and has also 

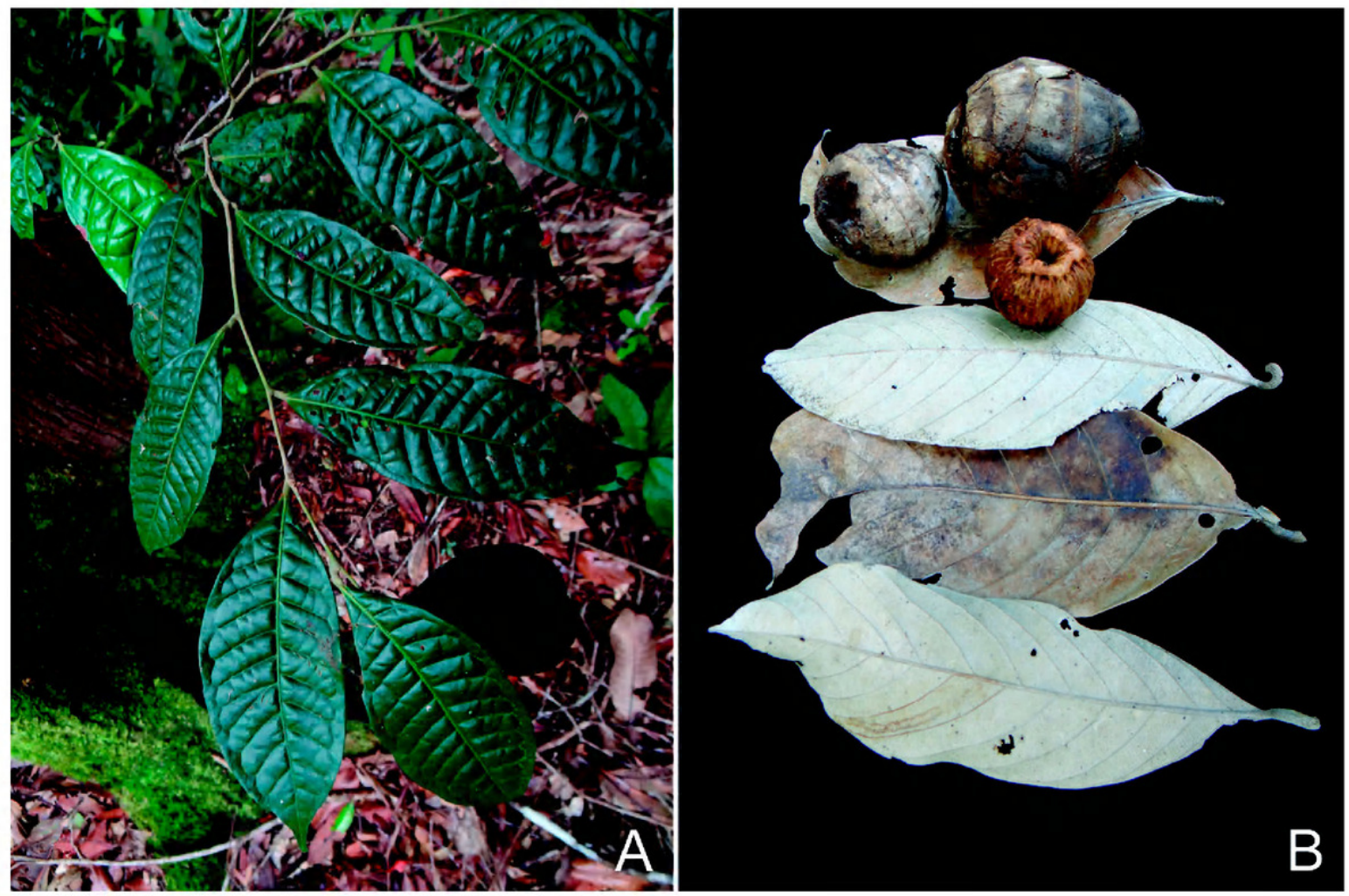

Fig. 4. New Lithocarpus records. A. Lithocarpus bullatus Hatus. ex Soepadmo. Wong WKM 3323. B. Lithocarpus hallieri (Seemen) A.Camus. Wong \& Jangarun WKM 3295. (Photos: K.M. Wong)

been recorded for the Mulu National Park (Sarawak), in Kalimantan (Indonesian Borneo), as well as on ultramafic soil in Beluran (Sabah) (Soepadmo et al., 2000). In Brunei, it is locally common in the hills around $1000 \mathrm{~m}$ in southern Temburong. The strongly bullate leaves are highly distinctive and no other Lithocarpus species approaches in this character.

Provisional IUCN conservation assessment. Least Concern (LC) (IUCN, 2012) for Brunei as there are good populations well within national parks, including the Ulu Temburong National Park.

Lithocarpus hallieri (Seemen) A.Camus, Riviera Sci. 18: 40 (1932). - TYPE: Borneo, Kalimantan, Mt. Lianggagang, Hallier 2655 (holotype BO; isotype L). (Fig. 4B)

Specimen examined. BRUNEI: Temburong: Ulu Temburong National Park, ridge W of LP 58, $1000 \mathrm{~m}$ asl, 6 Aug 2014, Wong \& Jangarun WKM 3295 (BRUN, SING).

This Bornean endemic tree is generally known for the other Bornean states and can be common in some localities, such as Ranau in Sabah.

The specimens were collected from a medium-sized tree to $35 \mathrm{~m}$ tall and $60 \mathrm{~cm}$ diameter. The acorns have cupules enveloping most of the nut and are large, the size of 
a fist (to $12 \mathrm{~cm}$ long, $10 \mathrm{~cm}$ diameter), obovoid and woody, with 5-7 distinct lamellae. The nut itself is c. $5 \mathrm{~cm}$ diameter.

Provisional IUCN conservation assessment. Data Deficient (DD) (IUCN, 2012) for Brunei as there is just a single collection, although several trees were seen on the ridges around the collection site. However, this status requires reassessment for a better understanding of its conservation status in Brunei, as more botanical explorations are made, especially to the largely inaccessible hills at the Brunei-Sarawak (Malaysia) border.

\section{MUSACEAE}

Musa lawitiensis Nasution \& Supard. var. suratii (Argent) Häkkinen, Adansonia 28(1): 60 (2006). - Musa suratii Argent, Gard. Bull. Singapore 52: 203 (2000). TYPE: Sabah, Tenom, Kallang, 8 September 1989, Surat \& Lamb 268/89 (holotype SAN; isotype E). (Fig. 5)

Specimens examined. BRUNEI: Temburong: Amo, Ulu Temburong National Park, Temburong river just downstream from Kuala Machang, true left bank, old landslip, 4'32'09'N 115¹2'13"E, $100 \mathrm{~m}$ asl, 17 May 2014, Lee et al. SL 1018 (BRUN, SING, IBSC), 18 May 2014, Wong et al. WKM 3274 (BRUN, SING).

Borneo, well within the centre of diversity for bananas, has 13 known species excluding the introduced Musa textilis Nee (Häkkinen, 2006). For Brunei, Coode et al. (1996) recorded only Musa borneensis Becc. (Hotta 13877), M. campestris Becc. (Bernstein 225, Coode 6792, Cowley 14, Hotta 12460, Johns 6800), and M. tuberculata M.Hotta (Hotta 13878), as well as the widely cultivated M. textilis (Hotta 13017).

Musa lawitiensis Nasution \& Supardiyono, endemic to Borneo, has four varieties (Häkkinen, 2006). Musa lawitiensis var. lawitiensis is known in W Kalimantan (Bentuan Karimun National Park) and Sarawak's Kapit Division; M. lawitiensis var. kapitensis and M. lawitiensis var. sarawakensis so far only from Sarawak's Kapit Division; and M. lawitiensis var. suratii from SW Sabah (Tenom), W Sarawak (Lubok Antu) and now Brunei (Temburong). Argent (2000), when publishing the original description of Musa suratii Argent, noted that this taxon was "clump forming" with suckers "vertical in young clumps but becoming angled outwards in the larger older clumps". He aptly described the plant looking "from a distance more like a Heliconia than a Musa as, in addition to the very slender habit, the leaves although actually spirally arranged are displayed more or less distichously in a single plane". Where we collected this plant beside the Temburong River, a small population of plants were seen with pseudostems typically inclined towards the river, so that the lower leaves were inserted spirally but more apical leaves assumed a pseudo-distichous arrangement: the sheaths showed spiral insertion clearly but the petioles oriented the leaf blades into essentially two rows, so that the banana had the habit of a large ginger from a distance. This habit would seem to adapt the plant to a good display of leaf surface on a steep earth bank. 

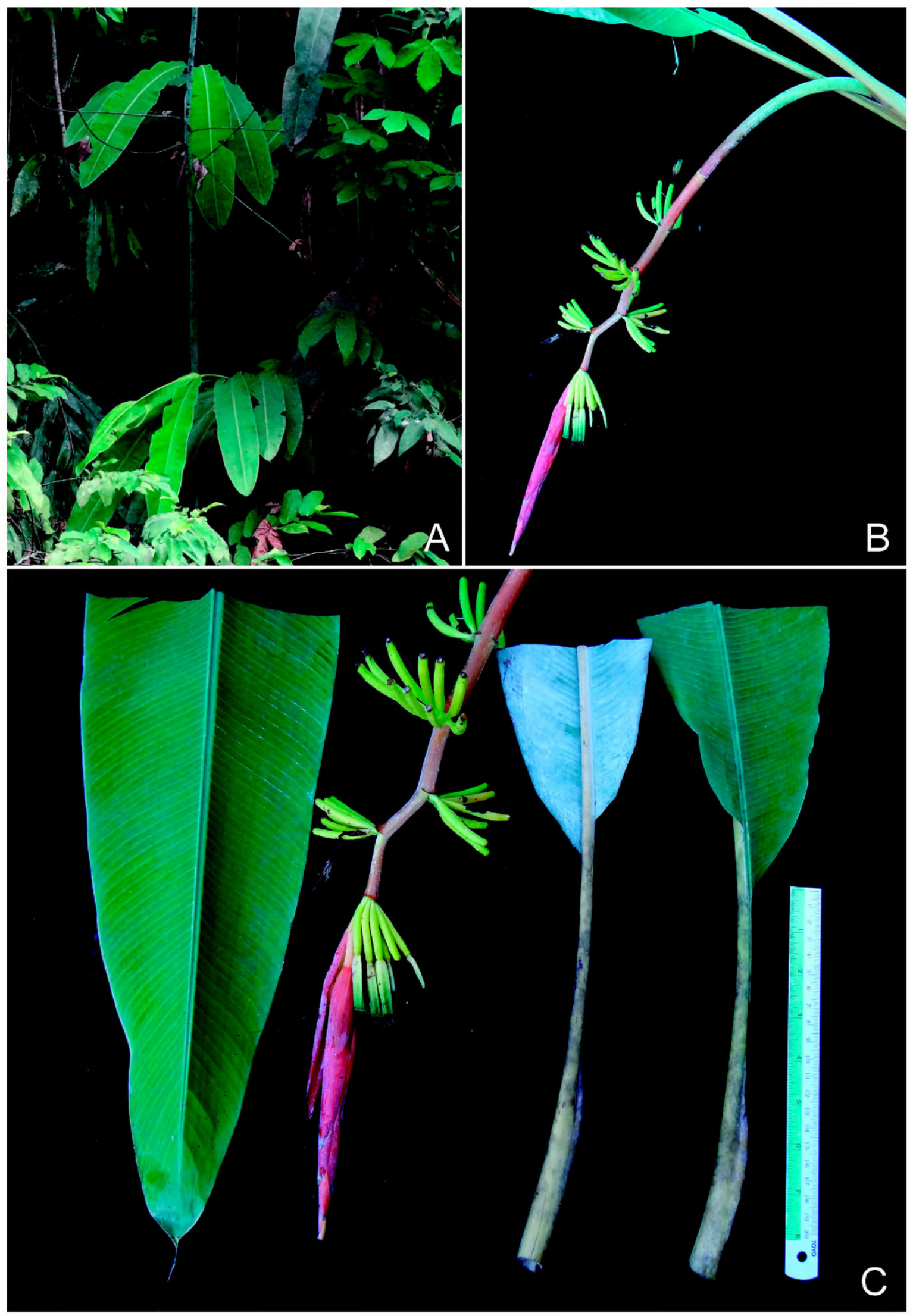

Fig. 5. Musa lawitiensis var. suratii (Argent) Häkkinen. Wong et al. WKM 3274. A. Habit. B. Downarched inflorescence with slender fruits. C. Characteristics of the leaf blade and inflorescence tip. (Photos: K.M. Wong) 
In the field, the leaning habit of this small slender banana (c. 3.5-4 m tall), with the narrow pseudo-distichous leaves that are richly waxy on their lower (abaxial) leaf surfaces, a horizontal to arching inflorescence, small slender fruits $(\mathrm{c} .10 \mathrm{~cm}$ long, c. $1.2 \mathrm{~cm}$ diameter), and very slender, orange-pink male bud with a sharp apex, are highly distinctive. The seeds are tuberculate, characteristic of Musa section Callimusa, and as many as 300 were counted for one fruit.

Provisional IUCN conservation assessment. Data Deficient (DD) (IUCN, 2012) for Brunei as the species is only known from the Ulu Temburong National Park, represented by two collections made on the same botanical fieldwork. Further field observations will contribute to a better understanding of its conservation status in Brunei.

\section{THYMELAEACEAE}

Aquilaria microcarpa Baill., Adansonia 11: 304 (1875). - TYPE: Borneo, Sarawak, 1872, Beccari PB 2886 (holotype FI [FI008102]; isotypes G [G00190871], L [L0010148], M [M0145881], NY [NY00386214], P [P00650666], S [S-G-553]). (Fig. 6)

Specimens examined. BRUNEI: Belait: Bukit Sawat, Jalan Meranking, 26 Jul 1997, Ogata Og-B 519 (BRUN); Kampong Merangking, 20 Dec 1994, Suhaili BRUN 16407 (BRUN); ibidem, 23 Jul 1999, Joffre BRUN 18367 (BRUN); Kampong Singap, Jalan Singap-Bukit, 24 Jun 1997, Said BRUN 18496 (BRUN); Sungai Liang, Arboretum, 7 Aug 1996, Clayton BRUN 16578 (BRUN); ibidem, 19 Aug 1997, Ariffin BRUN 18643 (BRUN). Brunei-Muara: Kilanas, Jalan Dadap waterfall, 16 Jun 1998, Noor Azam BRUN 18854 (BRUN). Temburong: Batu Apoi, 23 Apr 1935, Zainal KEP 30376 (BRUN, KEP); Bukit Patoi, 1959, Ashton Voucher 3689 (BRUN); Kuala Belalong, 15 May 2014, Lee et al. SL 974 (BRUN, SING). Tutong: Rambai, Ulu Sungai Tutong, Ulu Sungai Medit, 14 Aug 2009, Yusop BRUN 22684 (BRUN, K, KEP, L, SAN, SAR, SING); Tasik Merimbun, Bang Oncom, 19 Nov 1992, Bernstein JHB 358 (BRUN); Bukit Tangan, 16 Sep 2000, Suzuki K 13261 (BRUN, KAG).

An early checklist by Hasan \& Ashton (1964) listed Aquilaria malaccensis Lamk., which, although recorded for $\mathrm{N}$ and $\mathrm{E}$ Borneo (Hou, 1960), does not seem to be present in Brunei. The later checklist by Coode et al. (1996) confirmed the presence in Brunei of Aquilaria beccariana Tiegh. but left Bernstein JHB 358 (leafy twig only) unidentified. Aquilaria microcarpa is now verified by a number of collections of both flowering and fruiting specimens: the perianth is bell-shaped with lobes less than or equal the tube length and the fruit is subcordate and up to c. $1.5 \mathrm{~cm}$ long only (A. beccariana has floral tubes much longer than the lobes, and a longer obovoid fruit). Furthermore, its leaves dry olive to medium brown, whereas those of Aquilaria beccariana dry a pale golden brown. The latter species is more typical of kerangas, peatswamp and riverine (alluvial) forests in Mixed Dipterocarp Forest, whereas Aquilaria microcarpa is more generally recorded from Mixed Dipterocarp Forest on sandy clays. 


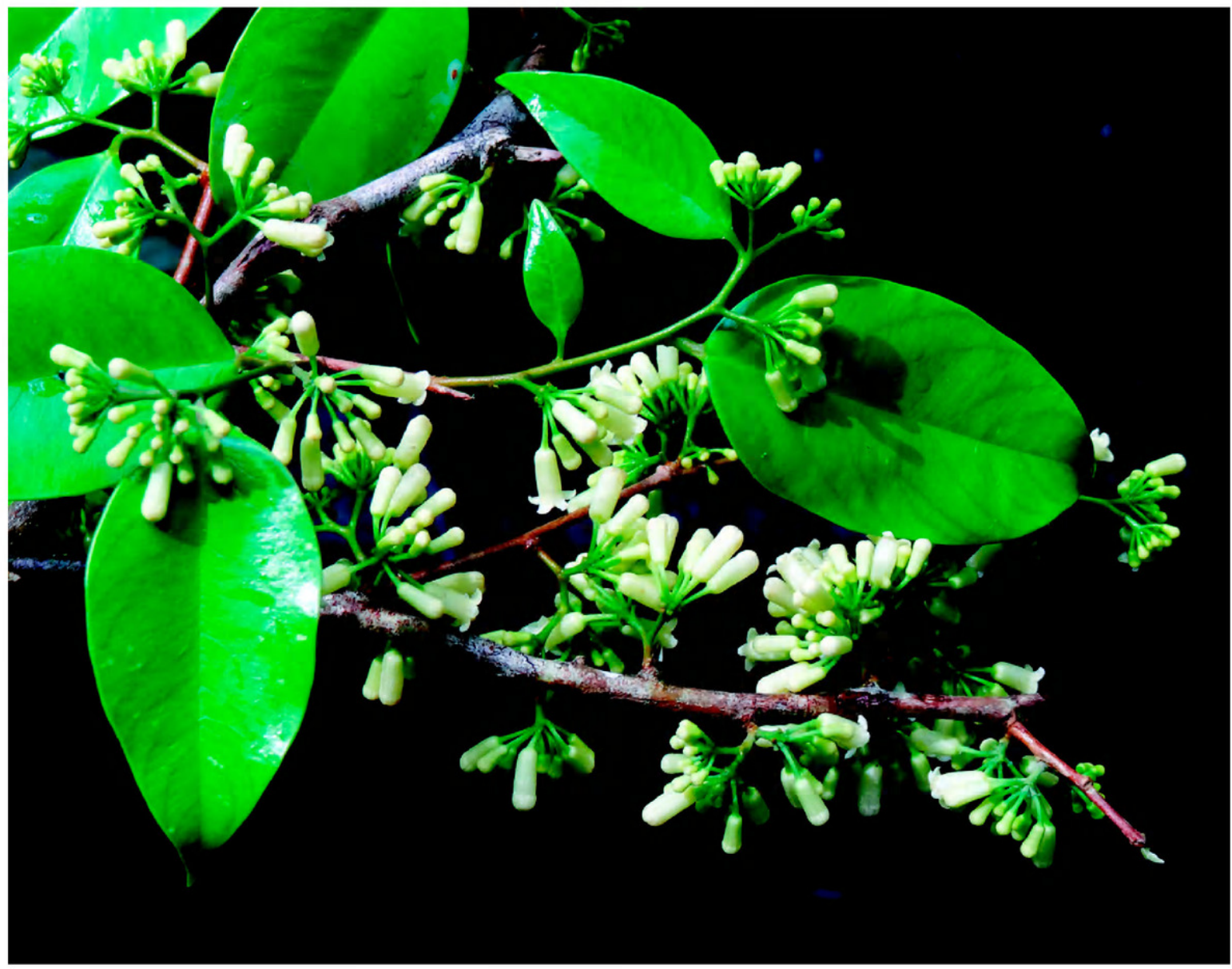

Fig. 6. Aquilaria microcarpa Baill. Flowering leafy branch. Lee et al. SL 974. (Photo: K.M. Wong)

Provisional IUCN conservation assessment. Least Concern (LC) (IUCN, 2001) for Brunei as the species is reasonably well collected with populations existing in the Ulu Temburong National Park, and other Forest Reserves and conservation areas, where logging is not permitted.

ACKNOWLEDGEMENTS. The Ministry of Industry and Primary Resources and the Forestry Department, Brunei Darussalam, and the National Parks Board and Botanic Gardens, Singapore, supported this work as part of their collaboration for A Botanical Survey of Brunei Darussalam. Field coordination and logistics were assisted through Noralinda binti Haji Ibrahim, Roslinah binti Haji Mohsin (Forestry Department), Watu bin Awok, Jangarun anak Eri and Azlan bin Pandai (BRUN); Serena Lee and Paul Parusuraman Athen (SING). We are grateful to the keepers and curators of the BO, BRUN, SAN, SAR and SING herbaria for facilitating study of specimens in their care. Specimen images were also accessed in Global Plants (continuously updated). 


\section{References}

Argent, G. (2000). Two interesting wild Musa species (Musaceae) from Sabah, Malaysia. Gard. Bull. Singapore 52: 203-210.

Beaman, J.H., Anderson, C. \& Beaman, R.S. (2001). The Plants of Mount Kinabalu 4. Dicotyledon Families Acanthaceae to Lythraceae. Kota Kinabalu: Natural History Publications (Borneo). (Araliaceae, Pp. 119-126)

Coode, M.J.E., Dransfield, J., Forman, L.L., Kirkup, D.W. \& Idris, M.S. (1996). A Checklist of the Flowering Plants and Gymnosperms of Brunei Darussalam. Brunei Darussalam: Ministry of Industry and Primary Resources.

Häkkinen, M. (2006). Musa lawitiensis Nasution \& Supard. (Musaceae) and its intraspecific taxa in Borneo. Adansonia 28(1): 55-65.

Hasan bin Pukol \& Ashton, P.S. (1964). A Check List of Brunei Trees. Reprinted 1988. Brunei Darussalam: Forestry Department.

Hou, D. (1960). Thymelaeaceae. In: Van Steenis, C.G.G.J. (ed) Flora Malesiana, Series I, 6: $1-48$.

IUCN (2012). IUCN Red List Categories and Criteria: Version 3.1. 2nd ed. Gland, Switzerland and Cambridge, UK: IUCN.

Global Plants (continuously updated). JSTOR® Global Plants. ITHAKA https://plants.jstor. org/ (accessed on 22 May 2015).

Philipson, W.R. (1979). Araliaceae-I. In: Van Steenis, C.G.G.J. (ed) Flora Malesiana, Series I, 9(1): 1-105.

Saw, L.G. (2012). A revision of Licuala (Arecaceae, Coryphoideae) in Borneo. Kew Bull. 67: $577-654$.

Soepadmo, E. (1970). Florae Malesianae Praecursores XLIX: Malesian species of Lithocarpus B1. (Fagaceae). Reinwardtia 8: 197-308.

Soepadmo, E., Julia, S. \& Go, R. (2000). Fagaceae. In: Soepadmo, E. \& Saw, L.G. (eds) Tree Flora of Sabah and Sarawak v 3: 1-117. Kuala Lumpur: Sabah Forestry Department, Forest Research Institute Malaysia \& Sarawak Forestry Department.

Thiers, B. (continuously updated). Index Herbariorum: A global directory of public herbaria and associated staff. New York Botanical Garden's Virtual Herbarium. http://sweetgum.nybg.org/ih/ (accessed on 31 May 2014).

Wen, J. (2004). Systematics and biogeography of Aralia L. sect. Dimorphanthus (Miq.) Miq. (Araliaceae). Cathaya 15-16: 1-187.

Yii, P.C. (1995). Araucariaceae. In: Soepadmo, E. \& Wong, K.M. (eds) Tree Flora of Sabah and Sarawak 1: 27-32. Kuala Lumpur: Sabah Forestry Department, Forest Research Institute Malaysia \& Sarawak Forestry Department. 


\section{$2 \mathrm{BHL}$ Biodiversity Heritage Library}

Wong, K. M. et al. 2015. "Novitates Bruneienses, 4. New records in the Araliaceae, Araucariaceae, Arecaceae, Fagaceae, Musaceae and Thymelaeaceae." The Gardens' bulletin, Singapore 67(2), 275-287. https://doi.org/10.3850/s238258121500023x.

View This Item Online: https://www.biodiversitylibrary.org/item/223140

DOI: https://doi.org/10.3850/s238258121500023x

Permalink: https://www.biodiversitylibrary.org/partpdf/229521

\section{Holding Institution}

Singapore Botanic Gardens, National Parks Board Singapore

\section{Copyright \& Reuse}

Copyright Status: In copyright. Digitized with the permission of the rights holder. License: http://creativecommons.org/licenses/by-nc-sa/4.0/ Rights: https://biodiversitylibrary.org/permissions

This document was created from content at the Biodiversity Heritage Library, the world's largest open access digital library for biodiversity literature and archives. Visit BHL at https://www.biodiversitylibrary.org. 